\title{
Epitinib Succinate
}

National Cancer Institute

\section{Source}

National Cancer Institute. Epitinib Succinate. NCI Thesaurus. Code C153095.

The succinate salt form of epitinib, an orally available epidermal growth factor receptor (EGFR) inhibitor, with potential antineoplastic activity. Upon administration, epitinib inhibits the activity of EGFR, thereby preventing EGFR-mediated signaling. This may lead to induction of cell death and inhibition of tumor growth in EGFR-overexpressing tumor cells. EGFR is a receptor tyrosine kinase (RTK) that is overexpressed in certain tumor types and plays a key role in tumor cell proliferation and vascularization. 